\title{
PPP2R5B wt Allele
}

National Cancer Institute

\section{Source}

National Cancer Institute. PPP2R5B wt Allele. NCI Thesaurus. Code C49443.

Human PPP2R5B wild-type allele is located within 11q12-q13 and is approximately $10 \mathrm{~kb}$

in length. This allele, which encodes serine/threonine-protein phosphatase 2A $56 \mathrm{kDa}$ regulatory subunit beta isoform protein, is involved in modulating both the substrate selectivity and catalytic activity of the core protein phosphatase 2A heterodimer. 